\title{
ABBREVIATED TITLES
}

\author{
AB Abercromby Papers. Henry E. Hunting- \\ ton Library. \\ Colden Papers The Letters and Papers of Cadwallader
} Colden. 9 vols. In New York Historical Society, Collections. New York, 1928.

Connecticut Charles J. Hoadly, ed. The Public Colonial Records Records of the Colony of Connecticut. 15 vols. Hartford, 1880.

Dinwiddie Louis K. Koontz, ed. Robert Dinwiddie Correspondence Correspondence, Illustrative of His Career in American Colonial Government and Westward Expansion. Berkeley and Los Angeles, 1951.

Dinwiddie R. A. Brock, ed. The Official Records of

Papers Robert Dinwiddie, Lieutenant Governor of the Colony of Virginia, 1751-1758. In Virginia Historical Society, Collections. Richmond, 1894.

Fitch Papers The Fitch Papers: Correspondence and Documents during Thomas Fitch's Governorship at the Colony of Connecticut, 1754-1766. 2 vols. In Connecticut Historical Society, Collections. Hartford, 1918.

Forbes, James A. Procter, ed. Writings of GenWritings eral John Forbes, Relating to His Service in North America. Menasha, Wisc., 1938.

Franklin Leonard W. Labaree, ed. The Papers of

Papers Benjamin Franklin. 15 vols. New Haven, 1959

HM Huntington Manuscripts. Henry E. Huntington Library. 
Johnson Papers James Sullivan et al., eds. The Papers of Sir William Johnson. 12 vols. Albany, 1921-1964.

Journals, Journals of the Massachusetts House of Massachusetts Representatives, 1715-1761. 37 vols. House Boston, 1919-1966.

LO Loudoun Papers. Henry E. Huntington Library.

New York E.B. O'Callaghan, ed. Documents RelaColonial Documents tive to the Colonial History of New York. 15 vols. Albany, 1856-1907.

Papers of Sylvester Stevens and Donald Kent, Colonel Bouquet eds. The Papers of Colonel Henry Bouquet. Harrisburg, 1941.

Papers of Sylvester K. Stevens and Donald Kent, Henry Bouquet

Pennsylvania

Archives

Pennsylvania Colonial Records eds. The Papers of Henry Bouquet, The Forbes Expedition. Harrisburg, 1951.

Samuel Hazard et al., eds. Pennsylvania Archives. 9 ser. 138 vols. Philadelphia and Harrisburg, 1853-1949.

Minutes of the Provincial Council of Pennsylvania from the Organization to the Termination of the Proprietary Government. 10 vols. Philadelphia, 1851-1853.

Pitt Gertrude Kimball, ed. The Correspond-

Correspondence ence of William Pitt. 2 vols. New York, 1906.

PRO/CO Public Record Office/Colonial Office

PRO/WO Public Record Office/War Office.

Rhode Island J. R. Bartlett, ed. Records of the Colony Colonial Records of Rhode Island and Providence Plantations in New England. 10 vols. Providence, 1856-1865.

Shirley Henry Lincoln, ed. The CorrespondCorrespondence ence of William Shirley. 2 vols. New York, 1912.

Votes ... N.Y., Votes and Proceedings of the General

PRO/CO Assembly of the Colony of New York.

Watts Letter Book of John Watts. In New

Letter Book York Historical Society, Collections.

New York, 1928. 